\title{
PREVALENCE AND PSYCHIATRIC COMORBIDITIESOF NOCTURNAL ENURESIS IN A SAMPLE OF BASIC EDUCATION STUDENTS IN SHARKIA GOVERNORATE
}

\author{
Hayam Elgohary, Asaad Shalanda, Saed El lethy \\ Psychiatry Department, Zagzazig University, Zagazig, Egypt

\section{ABSTRACT}

Background: Nocturnal enuresis and its psychiatric comorbidities are important psychosocial problem. Aim of the work: The aim is to study the prevalence and psychiatric comorbidities of nocturnal enuresis in 11 to 13 years' old children in Sharkia governorate.Subject and Method:A random sample of school students aged 11 to 13 years old in Sharkia Governorate (N. 603) applied a strucured questionair searching for nocturnal enuresis. The cases having nocturnal enuresis (N.50) and non enuretic control group (51) applied Children's Manifest Anxiety Scale, Children Depression Inventory, Abuse and neglect scale for children. Results: The overall prevalence was 8.29\% (50/603), depression, anxiety and child abuse are significantly associated with nocturnal enuresis. Conclusion: Our results with enuresis prevalence was comparable to other epidemiologic studies from various countries. Depression, anxiety and child abuse are more prevalent in enurtic child.

Keywords: nocturnal enuresis, prevalence, psychiatric co morbidities.

\section{INTRODUCTION}

$\mathbf{N}$ octurnal enuresis (NE) can be defined as the involuntary passage of urine during sleep beyond the age of anticipated nighttime bladder control, which is generally accepted as 5 years of age. Nocturnal enuresis is a very common clinical problem in children. ${ }^{[1]}$ Despite the fact that this condition usually labeled benign, it often leads to considerable emotional distress and concern in affected children. Prevalence of nocturnal enuresis is difficult to be estimated, the age and the diagnostic criteria are important variables that affect the prevalence. ${ }^{[2]}$ There is a spontaneous resolution rate of about $15 \%$ per year. ${ }^{[3]}$ The etiology of enuresis is not completely understood. This condition probably has a multifactor etiology. Most studies have consistently found that the risk factors are young age, family history; delayed maturation, bladder abnormality, urinary tract infection, stress, sleep disorders and vassopressin deficiency .In Sharkia there are no studies for prevalence and psychiatric co morbidities for nocturnal enuresis. ${ }^{[4,5,6,7,8,9,1,0]}$

\section{Aim of the work}

The aim is to study the prevalence and psychiatric co morbidities of nocturnal enuresis in 11 to13 years' old children in Sharkia governorate.

\section{Subject and Method}

The study is a sample survey as a across sectional study. It was done by stratified sample. One center (Zagazig center) was selected from Sharkia governorate. It has two educational administrations (east and west Zagazige) twelve schools were selected, six from each educational administration. Three from rural areas, the other three were selected from urban areas by simple random sample. The total number of the target population (the six grade primary school children and the first grade secondary school students, 11 to 13 years old) was obtained from the Statistics Bureau (Office)-Educational Directorate-Sharkia Governorate. The sample size was calculated (603 students) and the children were selected by cluster sample.

\section{Stage 1}

A self-administered structured questionnaire was distributed to all children, they are asked to hide it from each other to keep secrecy and privacy. The questionnaire asked about the name, the age, the gender of the child and the educational level of the parents. It asked also about having nocturnal enuresis.

\section{Stage II}

An interview was done with the cases that have nocturnal enuresis according to the Diagnostic and Statistical Manual of Mental Disorders (DSM-IV)for application of the Arabic version of:

\section{Children's Manifest Anxiety Scale "CMAS"}

Which is the modified form of Taylor anxiety scale Manifest Anxiety Scale "MAS".It was prepared for the Egyptian environment by doctor Veola El Beblawi. The scale involves 42 items to be answered by" yes" or "no", it represents the psychological, physiological and behavioral aspects of anxiety. ${ }^{[11]}$

\section{Children Depression Inventory (CDI)}

Which originaly prepared by Marya Kovacs who depended on Beck and Albert through many studies to applie the scale on children. It was prepared for the Egyptian environment by doctor Ghareeb $\mathrm{Ab}$ El Fatah.the scale involve 27 items that represent a wide range of depressive symptoms each item composed of three phrases from which the child choose only one that have a score from 0 to $2 .^{[12,13]}$

\section{And the Arabic Abuse and neglect scale for children.}


Which is a valid and reliable Arabic scale that measure the three aspects of child abuse physical, psychological and neglect. The scale measures the parents source of child abuse and neglect which is the important source in our study.Each aspect of child abuse is represented in 22 phrases, the child by self report choose one from four levels ( never, seldom, sometimes and many times). This scale was prepared for Arabic environment by professor doctor Amal Melegi Baza by the aid of other international scales. ${ }^{[14]}$

\section{Inclusion criteria}

1. Children of governmental and special schools in Sharkeia governorate.

2. All the sample children either males or females.

3. Children aged 11-13 years old.

4. Children who met the diagnostic criteria of DSM - IV.

\section{Exclusion criteria}

1. Mentally retarded children.

2. Children of age other than 11-13 years old

3. Children not met the DSM- IV criteria.

4. Those who have physical abnormalities

like epilepsy and spina pivda.

Statistical Analysis

Statistical package Epi-6 was used for statistical analysis. To test the statistical significance in the study, we used the $\chi^{2}$ and Fisher's exact test. Detected differences at $\mathrm{p}<0.05$ were considered to be significant.

\section{Results}

Mean age of the study group of children was $12.84 \pm 0.68$ years for cases and $12.90 \pm 0.67$ years for controls. In the study, number of cases was 50,28 of them were boys, and 22 of them were girls. Number of controls was 51, 24 of them were boys and 27 were girls. The overall prevalence of reported nocturnal enuresis was 82.9 per 1000 studied school children (50/603). All of the cases were considered primary cases.

There were no significant difference between boys and girls regarding prevalence. There was significant difference between cases and controls regarding anxiety, depression and abuse. The result showed higher prevalence of abuse and neglect in rural areas than in urban ones. There was no relationship between the educational level of the parents and the child abuse and neglect.

Anxiety was more prevalent in females than males. There was significant association between depression and anxiety, also between depression and abuse.

Table 1: Distribution by clinical findings among cases and control

\begin{tabular}{|c|c|c|c|c|c|c|c|}
\hline \multirow{2}{*}{ Studied variables } & \multicolumn{2}{|c|}{ Cases $(n=50)$} & \multicolumn{2}{|c|}{ Control $(n=51)$} & \multirow{2}{*}{$\begin{array}{l}\text { Odds } \\
\text { ratio }\end{array}$} & \multirow{2}{*}{$\begin{array}{c}\chi^{2} \\
\text { test }\end{array}$} & \multirow{2}{*}{$\begin{array}{c}\mathbf{P} \\
\text { value }\end{array}$} \\
\hline & No. & $\%$ & No. & $\%$ & & & \\
\hline \multicolumn{8}{|l|}{ Anxiety: } \\
\hline 1: high & 23 & 46.0 & 7 & 13.7 & -- & 28.92 & $<0.0001$ \\
\hline 2: moderate & 24 & 48.0 & 17 & 33.3 & & & \\
\hline 3: mild & 3 & 6.0 & 27 & 52.9 & & & \\
\hline total & 50 & 100.0 & 51 & 100.0 & & & \\
\hline \multicolumn{8}{|l|}{ Depression: } \\
\hline 1: high & 2 & 4.0 & 1 & 2.0 & -- & 25.51 & $<0.0001$ \\
\hline 2: moderate & 11 & 22.0 & 0 & 0.0 & & & \\
\hline 3: mild & 21 & 42.0 & 10 & 19.6 & & & \\
\hline 4: None & 16 & 32.0 & 40 & 78.4 & & & \\
\hline Total & 50 & 100.0 & 51 & 100.0 & & & \\
\hline \multicolumn{8}{|l|}{ Abuse: } \\
\hline 1:high & 8 & 16.0 & 1 & 2.0 & -- & 17.01 & $<0.001$ \\
\hline 2: moderate & 21 & 42.0 & 10 & 19.6 & & & \\
\hline 3: mild & 20 & 40.0 & 40 & 78.4 & & & \\
\hline 4: none & 1 & 2.0 & 0 & 0.0 & & & \\
\hline total & 50 & 100.0 & 51 & 100.0 & & & \\
\hline
\end{tabular}

Table 1 showed significant differences between cases and control regarding presence of anxiety, depression, and abuse 


\section{Table 2:Residence by clinical findings}

\begin{tabular}{lccccccc}
\hline \multirow{2}{*}{ Studied variables } & \multicolumn{2}{c}{ rural $(\mathrm{n}=34)$} & \multicolumn{2}{c}{ urban $(\mathrm{n}=16)$} & $\begin{array}{c}\text { Odds } \\
\text { ratio }\end{array}$ & $\begin{array}{c}\chi^{2} \\
\text { test }\end{array}$ & $\begin{array}{c}\text { P } \\
\text { Value }\end{array}$ \\
\cline { 2 - 5 } $\begin{array}{l}\text { Anxiety: } \\
\text { 1: high }\end{array}$ & 18 & 52.9 & 5 & 31.2 & & 3.10 & $>0.05$ \\
\hline 2: moderate & 15 & 44.1 & 9 & 56.3 & & & \\
\hline 3: mild & 1 & 3.0 & 2 & 12.5 & & & \\
\hline $\begin{array}{l}\text { Depression: } \\
\text { 1: high }\end{array}$ & 1 & 3.0 & 1 & 6.2 & & 7.21 & $>0.05$ \\
\hline 2: moderate & 9 & 26.4 & 2 & 12.5 & & & \\
\hline 3: mild & 17 & 50.0 & 4 & 25.0 & & & \\
\hline 4: non & 7 & 20.6 & 9 & 56.3 & & & \\
\hline
\end{tabular}

\begin{tabular}{lcccccc}
\hline $\begin{array}{l}\text { Abuse: } \\
\text { 1:high }\end{array}$ & 7 & 20.6 & 1 & 6.2 & 12.10 & $<\mathbf{0 . 0 1}$ \\
\hline 2: moderate & 18 & 52.9 & 3 & 18.8 & & \\
\hline 3: mild & 8 & 23.5 & 12 & 75.0 & & \\
\hline 4: none & 1 & 3.0 & 0 & 0.0 & & \\
\hline
\end{tabular}

Table 2 showed no significant differences between residence and all clinical findings as ( $p>0.05)$ except abuse which is higher among rural residents.

Table 3: Education of parents by clinical findings among cases

\begin{tabular}{|c|c|c|c|c|c|c|c|c|c|c|}
\hline \multirow[t]{2}{*}{ clinical findings } & \multicolumn{2}{|c|}{$\begin{array}{l}\text { Illiterate } \\
\quad(n=3)\end{array}$} & \multicolumn{2}{|c|}{$\begin{array}{l}\text { Read \&write } \\
\quad(\mathrm{n}=5)\end{array}$} & \multicolumn{2}{|c|}{$\begin{array}{l}\text { Moderate } \\
(\mathrm{n}=21)\end{array}$} & \multicolumn{2}{|c|}{$\begin{array}{l}\text { Unv. \&higher } \\
\quad(\mathrm{n}=21)\end{array}$} & \multirow{2}{*}{$\begin{array}{l}\chi^{2} \\
\text { test }\end{array}$} & \multirow{2}{*}{$\begin{array}{c}\mathrm{P} \\
\text { value }\end{array}$} \\
\hline & $\mathrm{NO}$ & $\%$ & No. & $\%$ & No. & $\%$ & No. & $\%$ & & \\
\hline Anxiety: & & & & & & & & & & \\
\hline 1: high & 2 & 66.7 & 2 & 37.5 & 11 & 52.4 & 9 & 42.8 & 1.79 & $>0.05$ \\
\hline 2: moderate & 1 & 33.3 & 3 & 62.5 & 9 & 42.8 & 10 & 47.7 & & \\
\hline 3: mild & 0 & 0.0 & 0 & 0.0 & 1 & 4.8 & 2 & 9.5 & & \\
\hline $\begin{array}{l}\text { Depression: } \\
\text { 1: high }\end{array}$ & 1 & 33.3 & 0 & 0.0 & 0 & 0.0 & 2 & 9.5 & 4.22 & $>0.05$ \\
\hline 2: moderate & 1 & 33.3 & 2 & 37.5 & 4 & 19.1 & 4 & 19.0 & & \\
\hline 3: mild & 0 & 0.0 & 2 & 37.5 & 10 & 47.6 & 8 & 30.1 & & \\
\hline 4: non & 1 & 33.3 & 1 & 25.0 & 7 & 33.3 & 7 & 33.4 & & \\
\hline $\begin{array}{l}\text { Abuse: } \\
\text { 1:high }\end{array}$ & 0 & 0.0 & 1 & 12.5 & 4 & 19.1 & 3 & 14.2 & 3.33 & $>0.05$ \\
\hline 2: moderate & 2 & 66.7 & 3 & 62.5 & 8 & 30.1 & 8 & 30.1 & & \\
\hline 3: mild & 0 & 0.0 & 1 & 12.5 & 8 & 30.1 & 10 & 47.7 & & \\
\hline 4: non & 1 & 33.3 & 0 & 0.0 & 1 & 4.7 & 0 & 0.0 & & \\
\hline
\end{tabular}

Table 3 showed no significant differences between level of education of parents and all clinical findings as $p$ $>0.05$ 
Table 4 : Relation between clinical findings and sex.

\begin{tabular}{|c|c|c|c|c|c|c|c|c|c|}
\hline \multirow{2}{*}{ Clinical finding } & \multicolumn{2}{|c|}{$\begin{array}{c}\text { Males } \\
(\mathrm{n}=28) \\
\end{array}$} & \multicolumn{2}{|c|}{ Females $(n=22)$} & \multirow{2}{*}{$\begin{array}{l}\text { Total } \\
\mathrm{N}=50\end{array}$} & \multirow{2}{*}{$\%$} & \multirow{2}{*}{$\begin{array}{l}\text { Odds } \\
\text { ratio }\end{array}$} & \multirow{2}{*}{$\begin{array}{c}\chi^{2} \\
\text { test }\end{array}$} & \multirow{2}{*}{$\begin{array}{c}\mathbf{P} \\
\text { value }\end{array}$} \\
\hline & No. & $\%$ & No. & $\%$ & & & & & \\
\hline $\begin{array}{l}\text { Anxiety: } \\
\text { 1: high }\end{array}$ & 9 & 32.1 & 14 & 63.6 & 23 & 46.0 & - & 6.80 & $<0.05$ \\
\hline
\end{tabular}

\begin{tabular}{lcccccc}
\hline 2: moderate & 18 & 64.3 & 6 & 27.3 & 24 & 48.0 \\
\hline 3: mild & 1 & 3.6 & 2 & 9.1 & 3 & 6.0 \\
\hline total & 28 & 56.0 & 22 & 44.0 & 50 & 100.0 \\
\hline
\end{tabular}

\section{Depression:}

1: high

$3.6 \quad 1 \quad 4.6$

$4.6 \quad 2 \quad 4$

2.82

$>0.05$

\begin{tabular}{|c|c|c|c|c|c|c|c|c|c|}
\hline 2: moderate & 7 & 25.0 & 4 & 18.2 & 11 & 22 & & & \\
\hline 3: mild & 9 & 32.1 & 12 & 54.6 & 21 & 42 & & & \\
\hline total & 17 & 60.7 & 17 & 77.2 & 34 & 68.0 & & & \\
\hline $\begin{array}{l}\text { Abuse: } \\
\text { 1:high }\end{array}$ & 4 & 14.3 & 4 & 18.2 & 8 & 16.0 & - & 1.49 & $>0.05$ \\
\hline 2: moderate & 13 & 50.5 & 8 & 36.4 & 21 & 42.0 & & & \\
\hline 3: mild & 10 & 35.7 & 10 & 45.4 & 20 & 4.0 & & & \\
\hline total & 27 & 96.4 & 22 & 100.0 & 49 & 98.0 & & & \\
\hline
\end{tabular}

Table 4 showed no significant differences between both sexes regarding all clinical findings as $\mathrm{p}>0.05$ except anxiety which is significantly higher among females $(\mathrm{p}<0.05)$.

Table 5: Relation between anxiety and other clinical findings.

\begin{tabular}{|c|c|c|c|c|c|c|c|c|}
\hline \multirow[t]{2}{*}{ clinical findings } & \multicolumn{2}{|c|}{ Sever anxiety $(n=23)$} & \multicolumn{2}{|c|}{$\begin{array}{c}\text { Moderate Anxiety } \\
(\mathrm{n}=24)\end{array}$} & \multicolumn{2}{|c|}{$\underset{(\mathrm{n}=3)}{\text { Mild Anxiety }}$} & \multirow{2}{*}{$\begin{array}{c}\chi^{2} \\
\text { test }\end{array}$} & \multirow{2}{*}{$\begin{array}{c}P \\
\text { value }\end{array}$} \\
\hline & No. & $\%$ & No. & $\%$ & No. & $\%$ & & \\
\hline $\begin{array}{l}\text { Depression: } \\
\text { 1: high }\end{array}$ & 2 & 8.7 & 0 & 0.0 & 0 & 0.0 & & \\
\hline 2: moderate & 9 & 39.1 & 2 & 8.3 & 0 & 0.0 & 18.78 & $<0.01$ \\
\hline 3: mild & 11 & 47.8 & 9 & 37.5 & 1 & 33.3 & & \\
\hline 4: non & 1 & 4.4 & 13 & 54.2 & 2 & 66.7 & & \\
\hline $\begin{array}{l}\text { Abuse: } \\
\text { 1:high }\end{array}$ & 6 & 26.1 & 2 & 8.3 & 0 & 0.0 & & \\
\hline 2: moderate & 12 & 51.2 & 9 & 37.5 & 0 & 0.0 & 24.09 & $<0.001$ \\
\hline 3: mild & 5 & 21.7 & 13 & 54.2 & 2 & 66.7 & & \\
\hline 4: none & 0 & 0.0 & 0 & 0.0 & 1 & 33.3 & & \\
\hline
\end{tabular}

Table 5 showed significant association between anxiety, depression, abuse 
Table 6: Relation between Depression and child abuse

\begin{tabular}{|c|c|c|c|c|c|c|c|c|c|c|}
\hline \multirow[t]{2}{*}{ clinical findings } & \multicolumn{2}{|c|}{$\begin{array}{c}\text { Severe depression } \\
\quad(\mathrm{n}=2)\end{array}$} & \multicolumn{2}{|c|}{$\begin{array}{c}\text { Moderate } \\
\text { depression } \\
(\mathrm{n}=11)\end{array}$} & \multicolumn{2}{|c|}{$\begin{array}{l}\text { Mild depression } \\
\qquad(\mathrm{n}=21)\end{array}$} & \multicolumn{2}{|c|}{$\begin{array}{c}\text { No } \\
\text { depression } \\
(\mathrm{n}=16)\end{array}$} & \multirow[t]{2}{*}{$\begin{array}{l}\chi^{2} \\
\text { test }\end{array}$} & \multirow[t]{2}{*}{$\begin{array}{c}\mathbf{P} \\
\text { value }\end{array}$} \\
\hline & No. & $\%$ & No. & $\%$ & No. & $\%$ & No. & $\%$ & & \\
\hline \multicolumn{11}{|l|}{ Abuse: } \\
\hline 1:high & 2 & 100.0 & 2 & 18.2 & 3 & 14.2 & 1 & 6.2 & 19.86 & $<0.05$ \\
\hline 2: moderate & 0 & 0.0 & 5 & 45.5 & 12 & 57.2 & 4 & 25.0 & & \\
\hline 3: mild & 0 & 0.0 & 4 & 36.3 & 5 & 23.8 & 11 & 68.8 & & \\
\hline 4: non & 0 & 0.0 & 0 & 0.0 & 1 & 4.8 & 0 & 0.0 & & \\
\hline
\end{tabular}

Table 6 showed significant association between depression and abuse $(\mathrm{p}<0.05)$.

\section{Prevalence}

In our findings, the overall prevalence of reported nocturnal enuresis was $8.29 \%$ in school children aged (11-13) years old using the DSM - IV diagnostic criteria (which need two voidings per week for diagnosis). Generally it is very difficult to estimate the exact prevalence of nocturnal enuresis, as multiple confounding factors can significantly influence the final result, as prevalence of NE is conditioned by the sample studied (age of the sample) and the definition used (diagnostic criteria).

Studies that include young aged children resulted in high prevalence like in the United States, Byrd et al, found the prevalence of NE $33 \%$ of 5 year aged children .Byrd considered as enuretic all children who reported one bedwetting episode in the year before the study which is considered another cause for that high prevalence - Also in Turkey where the prevalence of nocturnal enuresis was $17.9 \%$ as the study involved young aged children starting five years old ( 5-17-year-old age group). ${ }^{[15]}$

Another example, in Iran, enuresis was a complaint expressed by $16.2 \%$ of the cases in the study group (5 to 13 years old). ${ }^{[16]}$

Studies that used diagnostic criteria other than DSM- Iv resulted in high prevalence, some studies use ICD-10 which need only one voiding per month for diagnosis like in Turkey, where the prevalence of enuretic children according to the ICD-10 definition were $14.9 \%{ }^{[17]}$. Also in Saudi Arabia children the prevalence was $15 \%$ according to the ICD-10 definition the child age was 6-16. ${ }^{[18]}$

In Iran Mahmoodzadeh et al found a high prevalence of NE 18.7.In that study Nocturnal enuresis was defined as any intermittent incontinence while asleep in a child being at least five years old. This a reluctant, non strict definition for NE which may be the cause of that high prevalence. ${ }^{[19]}$

In Sydney the overall prevalence of any reported nocturnal enuresis was $18.9 \%$. The prevalence of marked nocturnal enuresis (at least weekly)was $7.8 \%{ }^{[20]}$

Butler et al estimated a $2.6 \%$ prevalence of NE, as defined by the DSM-Iv as diagnostic criteria, at 7.5 years of age, and reported that $12.8 \%$ had wetted the bed at some time. The strict diagnosis by the DSM is the cause of the relatively low frequency the non strict, non definite diagnosis (bed wetting at some time) resulted in high prevalence. ${ }^{[21]}$

Serel et al reported that $11.5 \%$ of children in their series, aged 7-12 years, had experienced bedwetting at some time in the year before the study, that prevalence is not based on a strict or demanding definition. The resulted prevalence is high comparable to the other studies. ${ }^{[22]}$

Spee van der Wekke et al, in a study conducted in The Netherlands, the overall prevalence of enuresis was $6 \%$, including children on special education. The sample of that was not homogeneous and a same definition of enuresis was not used for the whole sample. ${ }^{[23]}$

A study commissioned by the Italian Association of Parents of Enuretic Children to the Chiozza et al group, conducted on a sample of 6,892 children aged 6-14 years, found a 3.8\% prevalence of $\mathrm{NE}$ (which considered low frequency), as based on the DSM-III criteria. A detailed analysis of the age distribution of the study sample showed that it mostly consisted of children aged 12, 13, and 14 years. Specifically, children of these ages accounted for $43.94 \%$ of the series, while those of 6,7 , and 8 years, in whom enuresis would be more prevalent, only represented $24.47 \%$. This uneven distribution accounts for such a low prevalence. ${ }^{[24]}$

There is more than thirty studies all over the world for estimation of nocturnal enuresis 
frequency .The least number was $2.6 \% .{ }^{[21]}$ And the largest number was $18.7 \%$. ${ }^{[20]}$

The overall prevalence in our findings of nocturnal enuresis was $8.29 \%$ which generally is comparable to that wide range and difficult to be estimate prevalence of NE in all studies all over the world.

\section{Gender differences}

In our study there was no significant difference in prevalence of nocturnal enuresis between boys and girls. This result is similar to some reports in the literature. ${ }^{[25,26,17,19]}$.Although in some literature the prevalence of enuresis was more common in boys than in girls. ${ }^{[22,27,28,29,30,31]}$ .In theses studies the number of boys in the samples was more than that of girls. The significance of difference between boys and girls in these studies was not calculated.

\section{Psychiatric disturbances}

Studies focused on the effect of enuresis on the self esteem, self image and the psychosocial difficulties. $^{[32,28,33]}$ Other studies showed behavioral disorders like simple phobia ,anxiety disorders, disruptive behavior disorders, problems at school, mild reading difficulties as well as subclinical psychological symptoms. ${ }^{[34,35,29,36,37]}$

Some studies reported that psychiatric co morbidities are more common in children with day-time incontinence and secondary enuresis. In children with primary MEN, they are no more common than in the normal population $(10 \%$ to $20 \%$ ). They are most common in children with frequent voiding (40\% to $50 \%) \cdot{ }^{[38,39]}$. Although Byrd et al who considered as enuretic all children who reported one bedwetting episode in the year before the stud stated that enuretics in their series with very infrequent bedwetting had associated psychiatric disorder. In their opinion, diagnosis of children with such infrequent bedwetting, based on data reported in their article (less than six leakage episodes per year), the diagnostic criteria in that study was not strict(at least one monthly bedwetting episode should be calculated according to the ICD-10 definition). Their results cannot thus be compared to those of any other study. The group itself did not discuss their results as compared to those found in other countries. ${ }^{[40]}$ Our findings focused on depression and anxiety and showed significant difference between cases and controls regarding major depression disorder and anxiety, although all of our cases were primary nocturnal enuresis there was high prevalence of depression and anxiety. Although, studies reported no difference between primary enuresis and the normal population regarding psychiatric co morbidities. ${ }^{[38,39]}$
These results can be explained by: first, the relatively high frequency in our cases (we use the DSM diagnostic criteria which required two voidings per week), this is a high frequency in comparison to the other studies that used other diagnostic criteria like ICD-10(need one voiding per month for diagnosis) Second, the relatively old age of our cases (11-13 years) in comparison to the ages of children in other studies. The long duration of suffering from enuresis had been considered as a chronic stressor. Third, we use in our study specific scales for measuring depression, anxiety and child abuse, which involve wide ranges of symptoms that can accurately measure the change in the child behaviour while all other studies used child behaviour chick list, Rutter parent score and Behavior Problem Index.

\section{Abuse and neglect of enuretic children}

Our findings showed significant differences between cases and controls regarding child abuse and neglect, which is similar to literatures that reported high prevalence of child abuse either verbal or physical in enuretic patients like in Turkey and Barazil where the parental reactions to the child's enuresis were widely investigated. ${ }^{15,41}$.Also punitive attitude was still common in the local community of Hong Kong and this may adversely affect the parent-child relationship and their commitment to treatment. There was a significant correlation between the abuser's educational level and punishment severity. ${ }^{[42]}$

However our findings showed non significant differences between level of education of parents and child abuse as $p>0.05$, this may explained by the same culture and attitude towards the child even in different educational level in our society.

From the total number of our cases (50), two cases only sought medical advice, they were under medical treatment which means that $96 \%$ of cases did not seek medical advice, and this is great and warning result that denotes how much the neglect of those children. Kanaheswari in Malasia found in his study that $87 \%$ of cases had not sought any form of treatment despite $74 \%$ admitting to being embarrassed. ${ }^{[43]}$

In Turkey, however, the parental concern level was high; approximately half of the enuretic children did not visit a physician for management of the problem. ${ }^{[44]}$

Butler et al found that $40 \%$ of parents had tried the non medical strategies like fluid restriction and regular toileting at night. Although only $31.9 \%$ of those with nocturnal enuresis had seen a health worker. ${ }^{[21]}$ 
Only $63 \%$ of parents thought that medical intervention is a good way to deal with a child's bed-wetting $.6 .6 \%$ of the parents thought that medicines are a "very good way" to treat enuresis [45]

A lack of knowledge regarding the nature of enuresis and its negative effect on their children can cause parents to delay seeking medical advice. This lack of awareness is obvious in our society where the highest percentage of enuretic children don't seek medical advice.

\section{Level of parents education}

Our study showed non significant difference between cases and controls regarding the educational level of the parents .Some studies have reported parents of enuretics had low educational level ${ }^{[46,26,47,29]}$.Also in Iran the most recent study, there was low educational level of fathers in $48.3 \%$ and $62.8 \%$ in mothers ${ }^{[19]}$ in all that studies the educational level was classified in two categories only (Primary school or less and Junior high school or more ) in our study the educational level of the parents was classified to four categories which are more precise and more expressive(illiterate, read and write, moderate and university and higher)

In Turkey Gur et al found a relation between enuresis and the low educational level of the fathers, but there study had no control group. ${ }^{[25]}$

\section{Limitations:}

The results was dependent only on the child application of Children's Manifest Anxiety Scale "CMAS",Children Depression Inventory (CDI ), And the Arabic Abuse and neglect scale for children. It was difficult to meet the parents of the cases or controls to apply the parental versions of the scales.

\section{CONCLUSION}

In conclusion this study provides us with:

1. The prevalence of nocturnal enuresis in our locality which is a noticeably high prevalence. 2. Knowing how much the problem affects the child, (depression, child abuse and anxiety are highly associated with nocturnal enuresis)

\section{RECOMMENDATIONS}

1. A descriptive longitudinal study would also be helpful to describe the exact natural history of this disorder.

2. Because of the differences in NE type, frequency, a detailed prevalence study with stratification by subtype and age is required in order to ascertain NE incidence in our environment and differences in frequency.

\section{We can suggest:}

1. Secondary psychological damage should be prevented by advising against the punitive approach and for the supportive approach.
2. The importance of frequent follow-up with emotional support, reassurance and encouragement was reflected by the improvement of children's self concept and parent's perception of their behavior regardless of the treatment outcome.

\section{REFERENCES}

1.American Psychiatric Association (1994).Diagnostic and Statistical Manual of Mental Disorders.4thed. Washington, D.C.: American Psychiatric Association.

2 .M. Ramírez-Backhausa, *, S. Arlandis Guzmánb, G. García Fadriquea, Martínez Agullób, R. Martínez Garcíac and J.F. Jiménez-Cruza 2010 Nocturnal enuresis. A frequent problem with a difficult estimation of its prevalence actas urol esp.; 34(5):460-466.

3. Heilenkötter K, Bachmann C, Janhsen E, et al. (2006): Prospective evaluation of inpatient and outpatient bladder training in children with functional urinary incontinence. Urology.; 67:176-180.

4. Norgaard JP, Djurhuus JC, Watanabe H, Stenberg A, Lettgen B. Experience and current status of research into the pathophysiology of nocturnal Enuresis. Br J Urol 1997; 79:825-35.

5. Järvelin MR, Vikeväinen-Tervonen L, Moilanen I, Huttunen NP (January (1988): "Enuresis in seven-yearold children". Acta Paediatr Scand 77 (1): 148-53.

6. Djurhuus JC. Definitions of subtypes of enuresis Scan J Urol Nephrol Suppl 1999; 202:5-

7. Zink S, Freitag CM, von Gontard A. (2008): Behavioral comorbidity differs in subtypes of enuresis and urinary incontinence. J Urol.; 179:295-298.

8 .Wan J, Greenfield S. Enuresis and common voiding abnormalities. Pediatr Clin North Am 1997; 44: 1117-31.

9. Yeung CK, Chiu HN, Sit FK. Sleep disturbance and bladder dysfunction in enuretic children with treatment failure: fact or fiction? Scand J Urol Nephrol Suppl 1999; 202:20-3.

10. Norgaard JP, Pedersen EB, Djurhuus JC (1985): Dural anti-diuretic hormone levels in enuretics. $J$ Urol 134:1029-1031.

11. Castaneda, Alfred, palermo, D.S and Mc Candlless, Boyd R. (1956): Complex learning and performance as functio of anxiety in children and task difficulty. Child development 27, 328-32.

12. Albert, N., and Beck A. (1975):"Incidence of depression in early adolescence: preliminary study ". Journal of Youth and Adolescence, Vol .4 No.4.

13 .Kovacs, M., (1985) : "the Children s Depression Inventory (CDI)" Psychopharmacology Bulletin , Vol. 21,NO 4,PP.995-998.

14. Fried Nich, M.N.Einbender.N.J (1983): charactarstics of physical Abused Children.Journal of consulling and clinical Psychology.51, 313-314.

15. Can G, Topbas M, Okten A, Kizil M. Pediatr Int. (2004): Child abuse as a result of enuresis Feb; 46(1):64-6.

16. Gulumser Dolgun, Sevim Savaser, Serap Balci, and Saadet Yazici, (2012): Prevalence of Nocturnal Enuresis and Related Factors in Children Aged 5-13 in Istanbul Iran J Pediatr.June; 22(2): 205-212.

17. Ali Gunes, Gulsen Gunes, Yasemin Acik and Adem Akilli (2009): The epidemiology and factors associated with nocturnal enuresis among boarding and daytime school children in southeast of Turkey BMC Public Health September, 9:357.

18. Kalo BB, Bella H. Enuresis (1996): Prevalence and associated factors among primary school children in Saudi Arabia. Acta Paediatr; 85(10):1217-22. 
19. Hashem, Amestejani, Morteza, Karamyar, Mohammad, Nikibakhsh, Ahmad-Ali, (2013): Prevalence of Nocturnal Enuresis and Related Factors in Children Aged 5-13 in Istanbul Iran pediatr Feb, vol 23(no1) p59-64.

20. Bower WF, Moore KH, Shepherd RB, Adams RD. (1996): The epidemiology of childhood enuresis in Australia. Br J Urol.; 78(4):602-6.

21. Butler RJ, Golding J, Northstone K (2005): Nocturnal enuresis at 7.5 years old: Prevalence and analysis of clinical signs. BJU Int.; 96(3):404-10.

22 .Serel TA, Akhan G, Koyuncuoğlu HR, Ozturk A, Dogruer K, et al. (1997): Epidemiology of enuresis in Turkish Children. Scand J Urol Nephrol.; 31(6):537-9.

23. Spee-van der Wekke J, Hirasing RA, Meulmeester JF, Radder JJ. (1998): Childhood nocturnal enuresis in The Netherlands. Urology. 51(6):1022-6.

24. Chiozza ML, Bernardinelli L, Caione P, Del Gado R, Ferrara P, Giorgi PL, et al. (1998): An Italian epidemiological multicentre study of nocturnal enuresis. Br J Urol.; 81(Suppl 3):86-9.

25.Gür E, Turhan P, Can G, Akkus S, Sever L, Güzelöz S, Cifçili S, Arvas A. (2004): Enuresis: prevalence, risk factors and urinary pathology among school children in Istanbul, Turkey. Pediatr Int. Feb; 46(1):58-63.

26. Ozkan KU, Garipardic M, and Toktamis A, et al. (2004): Enuresis prevalence and accompanying factors in schoolchildren: A questionnaire study from southeast Anatolia. Urol Int; 73(2):149-5.

27.Chang P, Chen WJ, Tsai WY, Chiu YN. (2001): An epidemiological study of nocturnal enuresis in Taiwanese children. BJU Int.; 87(7):678-81.

28. Eapen V, Mabrouk AM. (2003): Prevalence and correlates of nocturnal enuresis in the United Arab Emirates. Saudi Med J Jan; 24(1):49-51.

29. Ozden C, L. Ozdal O, Altinova S, et al. (2007): Prevalence and Associated Factors of Enuresis in Turkish Children. International Braz J Urol; 33(2): 216-22.

30. De Sousa A, Kapoor H, Jagtap J, et al. (2007): Prevalence and factors affecting enuresis among primary school children. Indian J Urol; 23(4):354-7.

31.Wei Wang Q, Guo Wen J, Kui Song D, et al. (2007): Bedwetting in Chinese children: Epidemiology and predictive factors. Neurourol Urodyn; 26(4): 512-7.

32. Redsell SA, Collier J. Child Care Health Dev. (2001): Bedwetting, behaviour and self-esteem: a review of the literature. Child Care Health Dev Mar; 27(2):149-62.

33. Wolfe-Christensen C, Veenstra AL, Kovacevic L, Elder JS, Lakshmanan Y. (2012): Psychosocial difficulties in children referred to pediatric urology: a closer look. Urology. Oct; 80(4):907-12.

34. Liu X, Sun Z, Uchiyama M, Li Y, Okawa M. (2000): Attaining nocturnal urinary control, nocturnal enuresis, and behavioral problems in Chinese children aged 6 through 16 years. J Am Acad Child Adolesc Psychiatry.; 39(12):1557-64.

35. Yeung CK, Sihoe JD, Sit FK, Bower WF, Sreedhar B, Lau J (2004): Characteristics of primary nocturnal enuresis in adults: an epidemiological study. BJU Int 93:341-345.

36. Desta M, Hägglöf B, Kebede D, Alem A. (2007): Sociodemographic and psychopathologic correlates of enuresis in urban Ethiopian children. Acta Paediatr. Apr; 96(4):556-60. Epub 2007 Feb 14.

37. Esposito M, Carotenuto M, Roccella M, Minerva (2011): Pediatric Primary nocturnal enuresis and learning disability. Apr; 63(2):99-104.

38. von Gontard A. (2004): Psychological and psychiatric aspects of nocturnal enuresis and functional urinary incontinence. Urologe A. Jul; 43(7):787- 94.

39. Zink S, Freitag CM, von Gontard A. (2008): Behavioral comorbidity differs in subtypes of enuresis and urinary incontinence. J Urol.; 179:295-298.

40. Byrd RS, Weitzman M, Lanphear NE, Auinger P (1996): Bedwetting in US children: epidemiology and related behavior problems. Pediatrics 98:414-419.

41. Melina C. Sapi, Juliana S. P. Vasconcelos, Fernando G. Silva, Ronaldo Damião, Eloísio A. da Silva (2009): Assessment of domestic violence against children and adolescents with enuresis.Jornal de Pediatria - ISSN 1678-4782 • Volume $85 \cdot \mathrm{N}^{\circ} 5 \cdot \mathrm{Sep} / \mathrm{Oct}$.

42. CFN Ng, SN Wong (2004):"Primary Nocturnal Enuresis: Patient Attitudes and Parental Perceptionss". Hong Kong Journal of Paediatrics. vol;9:54-58.

43. Kanaheswari Y. (2003): Epidemiology of childhood nocturnal enuresis in Malaysia. Enuresis: a contrast of attitudes of parents and physicians. J Paediatr Child Health. Mar; 39(2):118-23.

44. Inan M, Tokuc B, Aydiner CY, Aksu B, Oner N, Basaran UN(2008): Personal characteristics of enuretic children: an epidemiological study from South-East Europe.Urol Int81(1):47-53.

45. Shelov SP, Gundy J, Weiss JC, McIntire MS, Olness K, Staub HP, Jones DJ, Haque M, Ellerstein NS, Heagarty MC, Starfield B. (1981): Enuresis: a contrast of attitudes of parents and physicians.Pediatrics. May; 67(5):707-10 46. Cher TW, Lin GJ, Hsu KH. (2002): Prevalence of nocturnal enuresis and associated familial factors in primary school children in Taiwan. J Urol.; 168(3):11426.

47. Tai HL, Chang YJ, Chang SC, Chen GD, Chang CP, Chou MC: (2007): The epidemiology and factors associated with nocturnal enuresis and its severity in primary school children in Taiwan. Acta Paediatr; 96(2):242-5 


\section{الملخص العربى}

التبول الليلى لدى الأطفال من المشكلات الصحية التى لها بالغ الاثر على الحالة النفسية للطفل.و الهدف من هذه التهات الدر اسـه هو معرفة

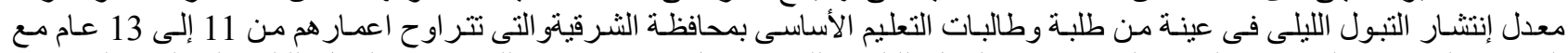

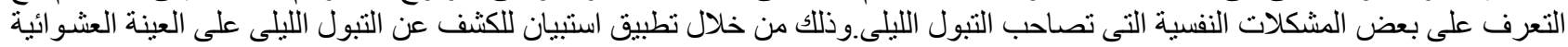

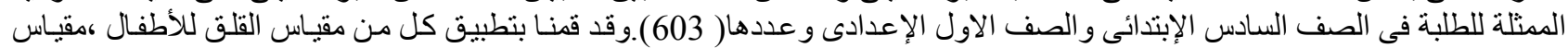

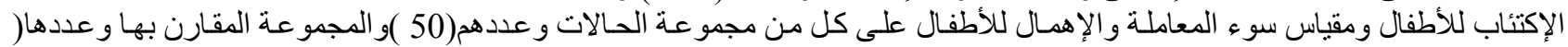

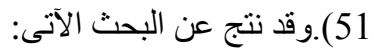
معدل إنتشار التبول الليلى فى العينة الإنى المدثلة للمحافظة يمكن مقارنته بالنسب العالمية و هو

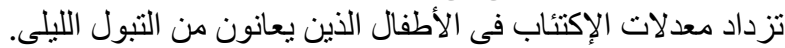

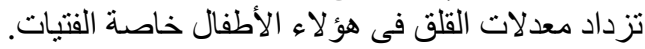

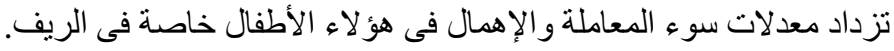

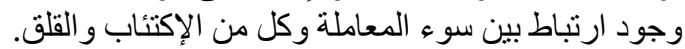

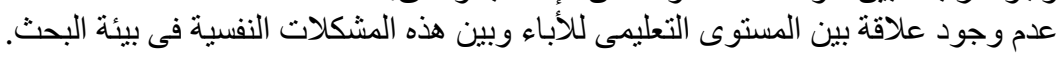

